\title{
Histopathological and Ultrastructural Effects of $\delta$-endotoxins of Bacillus thuringiensis Serovar israelensis in the Midgut of Simulium pertinax Larvae (Diptera, Simuliidae)
}

\author{
CFG Cavados/ ${ }^{+}$, S Majerowicz*, JQ Chaves*, CJPC Araújo-Coutinho**, L Rabinovitch
}

Departamento de Bacteriologia *Departamento de Virologia, Instituto Oswaldo Cruz- Fiocruz, Av. Brasil 4365, 21045-900 Rio de Janeiro, RJ, Brasil **Superintendência de Controle de Endemias, Secretaria de Saúde do Estado de São Paulo, São Paulo, SP, Brasil

The bacterium Bacillus thuringiensis $(B t)$ produces parasporal crystals containing $\delta$-endotoxins responsible for selective insecticidal activity on larvae. Upon ingestion, these crystals are solubilized in the midgut lumen and converted into active toxins that bind to receptors present on the microvilli causing serious damage to the epithelial columnar cells. We investigated the effect of these endotoxins on larvae of the Simulium pertinax, a common black fly in Brazil, using several concentrations during $4 \mathrm{~h}$ of the serovar israelensis strain IPS-82 (LFB-FIOCRUZ 584), serotype H-14 type strain of the Institute Pasteur, Paris. Light and electron microscope observations revealed, by time and endotoxin concentration, increasing damages of the larvae midgut epithelium. The most characteristic effects were midgut columnar cell vacuolization, microvilli damages, epithelium cell contents passing into the midgut lumen and finally the cell death. This article is the first report of the histopathological effects of the Bti endotoxins in the midgut of S. pertinax larvae and the data obtained may contribute to a better understanding of the mode of action of this bacterial strain used as bioinsecticide against black fly larvae.

Key words: Bacillus thuringiensis serovar israelensis - Simulium pertinax - midgut - histopathology - ultrastructure

Bacillus thuringiensis (Bt) is a Gram-positive, aerobic bacterium, producing parasporal crystals containing $\delta$ endotoxins responsible for its selective insecticidal activity (Knowles 1994, Schnepf et al. 1998) during the III to V step of sporulation. Upon ingestion by susceptible insects, these crystals are dissolved in the midgut lumen. Under the action of intestinal proteases, the endotoxins are converted into active toxins that bind to receptors present on the microvilli, causing strong damages to the epithelial midgut cells (Gill 1992, Aronson \& Shai 2001, Ruiz et al. 2004).

Most of the simuliids are hematophagus insects; they are involved in the transmission of human onchocerciasis, mainly in the North of Brazil. Simulium pertinax is the most important species in Southeast region inducing a negative socio-economic impact. The frequent and intensive attacks by $S$. pertinax on the transitory populations in this area helps to reduce tourism during summer months (Gerais \& Ribeiro 1986, Araújo-Coutinho 1995, MaiaHerzog et al. 1999, Cavados et al. 2001, Araújo-Coutinho et al. 2003).

After isolation of the B. thuringiensis serovar israelensis (Bti) by Goldberg and Margalit (1977) and its characterization by De Barjac (1978), several studies were realized confirming the action of Bti as a larvicide mainly

${ }^{+}$Corresponding author: Fax: +55-21-2270.6565. E-mail: ccavados@ioc.fiocruz.br

Received 26 February 2004

Accepted 18 June 2004 for controlling Simulium and Aedes species (De Barjac 1978, Lacey et al. 1982, Charles \& De Barjac 1983, Becker 1990, Araújo-Coutinho 1995, Mardini et al. 1999, Rabinovitch et al. 1999, Cavados et al. 2001, Regis et al. 2001).

Histophatological investigations in larvae of $S$. vittatum infected with $B$. thuringiensis serovar kurstaki HD 255 (Lacey \& Federici 1979) and S. variegatum infected with Bti (Rey et al. 1998) demonstrated morphological lesions in the intestinal epithelium which exhibited swollen cells, degenerated brush borders, disorganized nuclei, enlargement of intercellular spaces and cell lysis.

The present report describes sequential changes in the midgut of $S$. pertinax larvae infected with increasing concentrations of $\delta$-endotoxins of Bti using light and electron microscope methodologies, information relevant to black flies control.

\section{MATERIALS AND METHODS}

Bacterial strain - Bti strain IPS-82 (LFB-FIOCRUZ 584), serotype H-14 type strain of the Institute Pasteur, Paris. It was maintained in agar medium with metals-ANM at room temperature (Rabinovitch et al. 1975).

Culture medium - The bacterial biomass was prepared using a fermentation medium based on soya flour and metals ( such as $\mathrm{Mg}^{2+}, \mathrm{Mn}^{2+}, \mathrm{Zn}^{2+}, \mathrm{Fe}^{2+}$ and $\mathrm{Ca}^{2+}$ ) developed in the Laboratório de Fisiologia Bacteriana, Departamento de Bacteriologia, IOC-Fiocruz (Cavados et al.1998, Rabinovitch et al.1998).

Inoculum and biomass production - Growth started with a pre-inoculum to reduce the duration of the lagphase of bacterial growth. After inoculation in $125 \mathrm{ml} \mathrm{Er}$ lenmeyer flasks containing $50 \mathrm{ml}$ of the medium, the flasks were incubated in a New Brunswick Scientific agitator 
series $25 \mathrm{D}$, at $175 \mathrm{opm}$ and $30^{\circ} \mathrm{C}$ for $6 \mathrm{~h}$. Subsequently, 3 $\mathrm{ml}$ were transferred to $500 \mathrm{ml}$ Erlenmeyer flasks containing $150 \mathrm{ml}$ of the soya flour and metals medium and incubated as previously described for a further $72 \mathrm{~h}$ period. Once sporulation had reached a level of $95 \%$ of free spores and crystals, each culture was centrifuged $\left(6000 \mathrm{~g}, 10^{\circ} \mathrm{C}\right)$, the biomasses were kept in an amber container with the $\mathrm{pH}$ adjusted to 5.0 with propionic acid and then formulated (Rabinovitch et al. 1998).

Bioassay with S. pertinax larvae - S. pertinax larvae were collected in the Soberbo river in the municipality of Guapimirim, state of Rio de Janeiro. Field-collected larvae were maintained in chambers where the water was aerated by a continuous stream of air bubbles. Biological insecticide doses equivalent to $2,4,6 \mathrm{mg} / \mathrm{l}$ were applied to the different groups of larvae. The exposure times employed ranged from 1 to $4 \mathrm{~h}$. Only live larvae were examined. At the end of each time period the larvae were observed under a stereoscopic microscope and the head and anal region were dissected and discarded (Cavados 2000). The remainder of the larval body was fixed and processed for observation using light and electron microscopy.

Light microscopy (LM) - Semi-thin sections were made from intestine samples previously embedded in Epon, stained with a methilene blue-azure II solution in phosphate buffer 0.2 M, pH 6.9 (Richardson et al. 1960, Humprey \& Pittman 1974) and observed in a Zeiss Axiophot microscope.

Electron microscopy (TEM) - Samples of the intestine were fixed in $2.5 \%$ glutaraldehyde in $0.2 \mathrm{M}$ cacodylate buffer, $\mathrm{pH} 7.2$, then washed in cacodylate buffer containing $7.2 \%$ sucrose, post-fixed in $1 \%$ osmium tetroxide for 1:45 $\mathrm{h}$, dehydrated in graded acetone and embedded in Epon. Ultrathin sections were stained with uranyl acetate and lead citrate (Reynolds 1963) and examined with a Zeiss EM-900 electron microscope.

\section{RESULTS}

The non-infected Simulium control midgut shows a well-preserved layer of epithelial cells. The ovoid shaped nuclei are located in the center of the cell (Fig. 1). Long and regularly placed microvilli border the midgut lumen (Fig. 2).

The midgut of the larvae exposed to Bti using $2 \mathrm{mg} / \mathrm{l}$ shows some cells presenting an irregularly structured brush border within 1 to $2 \mathrm{~h}$ (Fig. 3 ). The cells begin to be swollen by a slight vacuolization and increasing of secretion vesicles. (Fig. 4). This feature is confirmed when observed by ultrastructure (Fig. 5). From 3 to $4 \mathrm{~h}$ after applying the endotoxin, structural changes occur in some of the epithelial cells (Fig. 8), whereas other ones maintain its morphology (Fig. 7). In addition, cell groups observed at the basis of the epithelium suggest a beginning of tissue recovery (Fig. 6).

When the midgut of larvae exposed to $4 \mathrm{mg} / \mathrm{l}$ of the endotoxin is analyzed after 1 to $2 \mathrm{~h}$, it shows increased morphological changes of the epithelium with most of the cells swollen, vacuolated, with an increased number of secretion vesicles and an irregularly disposed brush border (Fig. 9). After 3 to 4 h, the pathological effects are observed in nearly all of the intestinal cells. The epithe- lium presents detached cells also with bubble shape tips (Fig. 10) and cells with short and thick (Fig. 11), irregularly and modified microvilli (Fig. 12).

When $6 \mathrm{mg} / \mathrm{l}$ of the bioinsecticide are employed, the midgut can only be analyzed during the first hour of exposure to the endotoxin, since after this time all the larvae are dead. The structural disorganization of the intestinal epithelium is evident, showing cells without the characteristic morphology (Fig. 13), becoming elongated, presenting destroyed tips and sometimes budding into the intestine lumen (Figs 14, 15).

\section{DISCUSSION}

In our experiments, which were stopped after $4 \mathrm{~h}$ of exposure to the Bti endotoxin, $S$. pertinax larvae could survive when a low concentration of Bti $(2 \mathrm{mg} / \mathrm{l})$ was applied. Histological alterations of some columnar cells of the midgut epithelium during the exposure to the endotoxin were observed. Nevertheless, after $4 \mathrm{~h}$ of toxin action well preserved groups of cells located at the base of the epithelium next to the basal membrane (Fig. 6) indicated that cell recovery was in progress. Increasing the endotoxin concentration $(4 \mathrm{mg} / \mathrm{l})$ nearly all columnar-cells were affected after $3 \mathrm{~h}$ of exposure to Bti endotoxin and no preserved cell groups next to the basal membrane of the midgut could be detected, though the larvae had not yet died. When $6 \mathrm{mg} / \mathrm{l}$ of the endotoxin were applied, all the larvae died after $1 \mathrm{~h}$.

Using Bti at a very low concentration $(0.4 \mathrm{mg} / \mathrm{l})$ during routine field application against $S$. variegatum, Rey et al. (1998) observed that $72 \mathrm{~h}$ after the beginning of the treatment all black flies died, but only $15.7 \%$ after $24 \mathrm{~h}$ of treatment. Lacey and Federici (1979) using a concentration of $10 \mathrm{mg} / \mathrm{l}$ of B. thuringiensis serovar kurstaki against $S$. vittatum larvae noted that mortality was increased by temperature elevation. In another experiment, Charles and de Barjac (1983) using $0.08 \mathrm{mg} / \mathrm{l}$ of purified Bti crystals against the larvae of Aedes aegypti, reported that all were dead after $10 \mathrm{~h}$. Lahkim-Tsor et al. (1983) used $10 \mathrm{mg} / \mathrm{l}$ of Bti for Ae. aegypti larvae feading and found that the larvae died between 37 and 120 min after the beginning of exposure to the endotoxin. Regarding these experiments, the cytopathic effects observed in larvae midguts were proportional to Bti endotoxin concentrations applied and inversely proportional to the time of exposure. The endotoxin concentrations used in our experiments gave a clear idea of $S$. pertinax larvae resistance.

Ultrastructural observations showed that the first cell damages due to the Bti endotoxin in the S. pertinax larvae midgut were related to brush border microvilli degeneration. As illustrated in Percy and Fast (1983) using purified Bt crystal toxin (1 g/l) against silkworm larvae, the dissolution of cytoskeleton structures inside and at the basis of the microvilli were responsible for its decrease in size and further disappearance, when bubbles of cytoplasmic substances protrude into the midgut lumen as in S. pertinax (Figs 4, 7, 14). At this stage, before the cell death, the columnar cells appeared more elongated in light microscope observations (Fig. 9).

The use of $B$. thuringiensis endotoxins originated vacuolization of the midgut epithelial cells in the different 

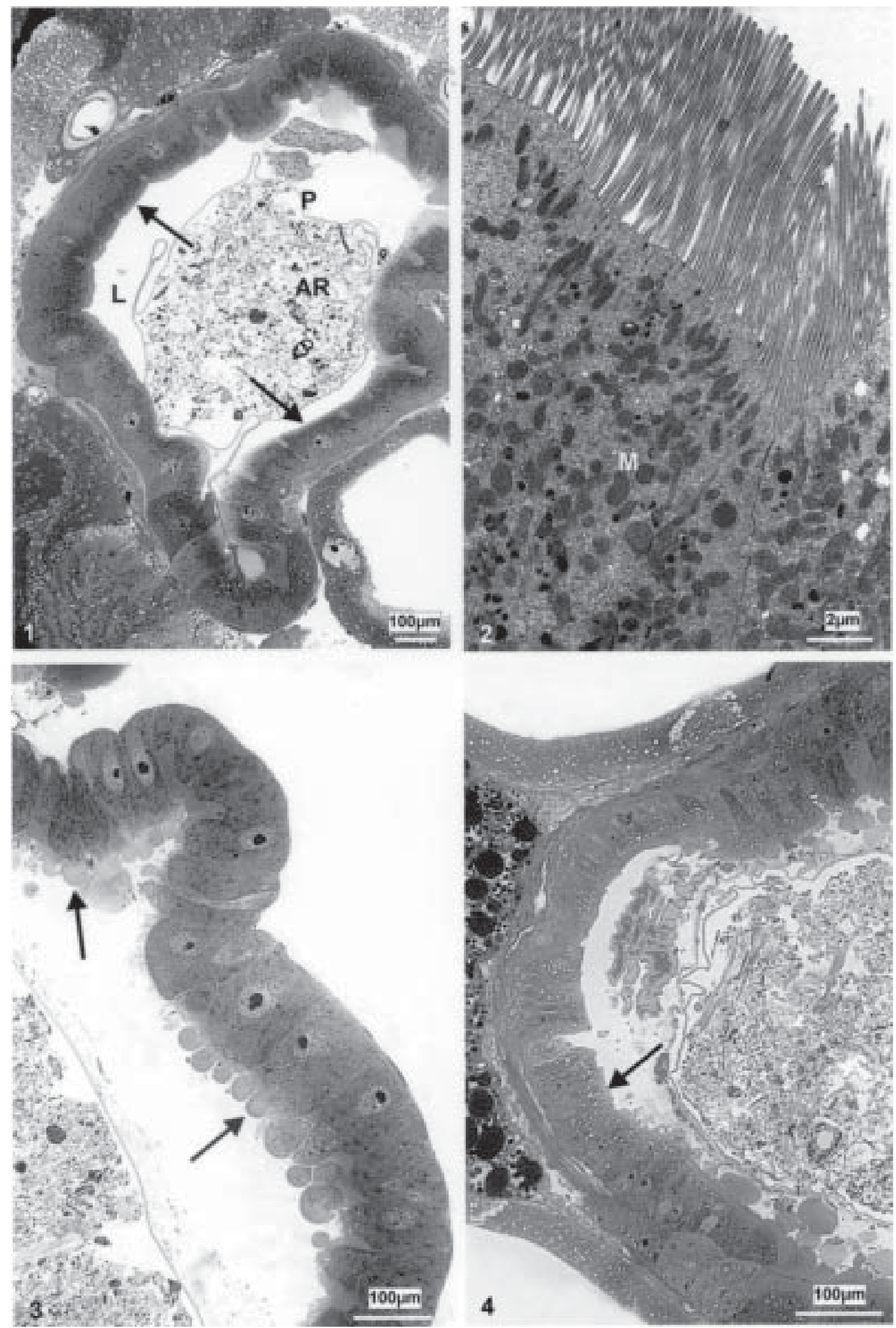

Fig. 1: the continuous brushborder (arrows) characterizes the midgut epithelium in control larvae of Simulium pertinax. L: intestinal lumen; P: peritrophic membrane; AR: alimentar residues; semithin section. Fig. 2: longitudinal section of microvilli of a columnar cell of the midgut in a control larva of S. pertinax. M: mitochondria; transmission electron micrograph. Fig. 3: columnar cells of the midgut of a larvae after treatment of $2 \mathrm{~h}$ with $2 \mathrm{mg} / \mathrm{l}$ of Bacillus thuringiensis serovar israelensis (Bti) suspension. Note cell swelling and strong emission of secreted bubbles (arrows). Fig. 4: columnar cells of the midgut of a larva after treatment of $4 \mathrm{~h}$ with $2 \mathrm{mg} / \mathrm{l}$ of Bti suspension. Note the strong vacuolization of columnar cells, partially non-altered brush borders (arrow) and strongly altered columnar cells with secreted bubbles. 

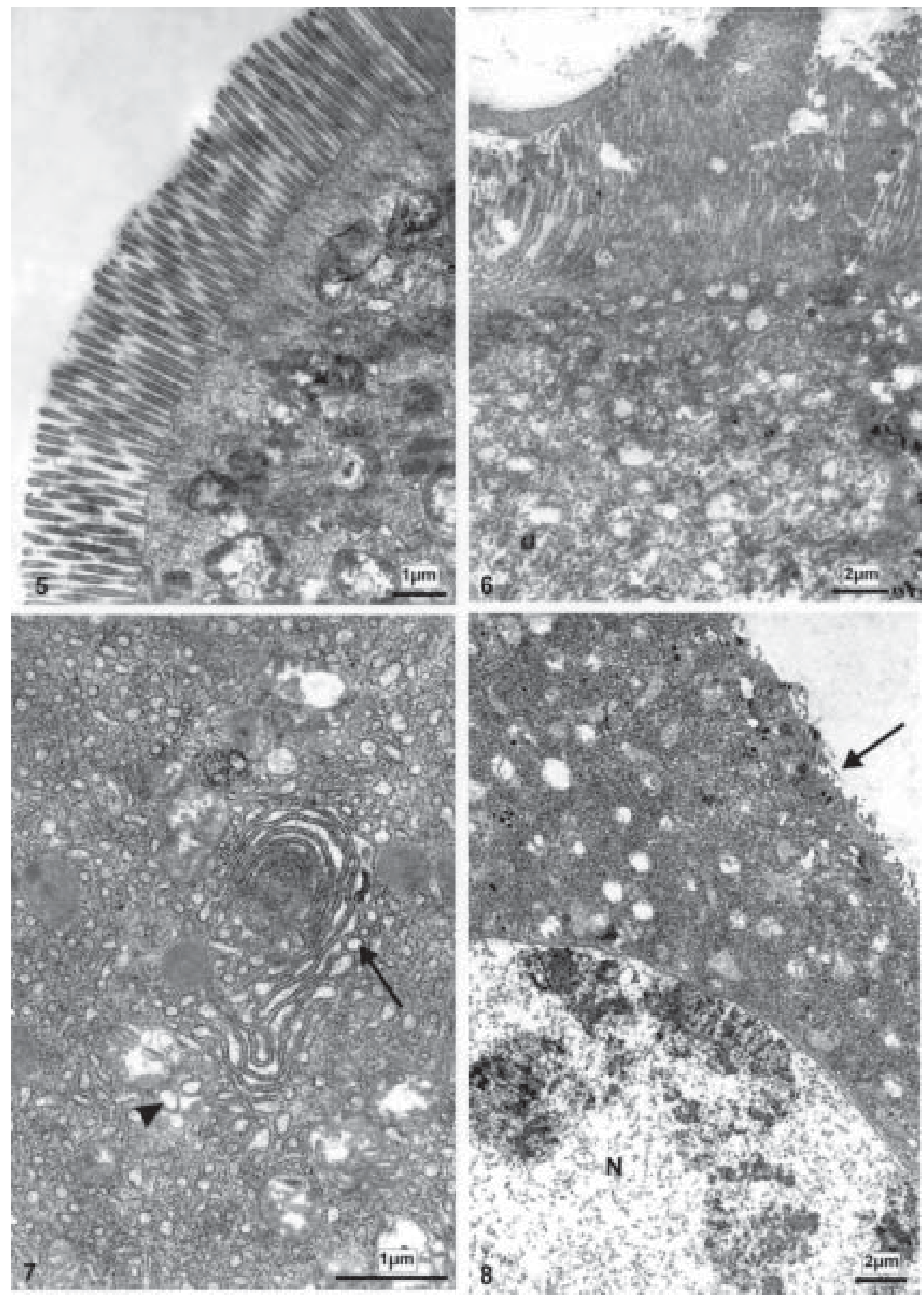

Fig 5: columnar cell of the midgut of a larva after treatment of $3 \mathrm{~h}$ with $2 \mathrm{mg} / \mathrm{l}$ of Bacillus thuringiensis serovar israelensis (Bti) suspension. Note non-altered microvilli but strong alterations of cytoplasmic structure and organelles; transmission electron micrograph. Fig. 6: columnar cell of the midgut of a larva after treatment of $4 \mathrm{~h}$ with $2 \mathrm{mg} / \mathrm{l}$ of Bti suspension. Note strongly altered microvilli and secreted substances between and also cell vacuolization. Fig. 7: columnar cell of the midgut of a larva after treatment of $2 \mathrm{~h}$ with $2 \mathrm{mg} / \mathrm{l}$ of Bti suspension. Note proliferation of rough endoplasmic reticulum derived vesicles (arrow) that in sequence lost their ribosomes (arrowhead). Fig. 8: columnar cell of the midgut of a larva after treatment of $2 \mathrm{~h}$ with $2 \mathrm{mg} / \mathrm{l}$ of Bti suspension. Note the fragmented chromatin inside the nucleus $(\mathrm{N})$, vacuolization of the cytoplasm and destroyed brush border (arrow). 

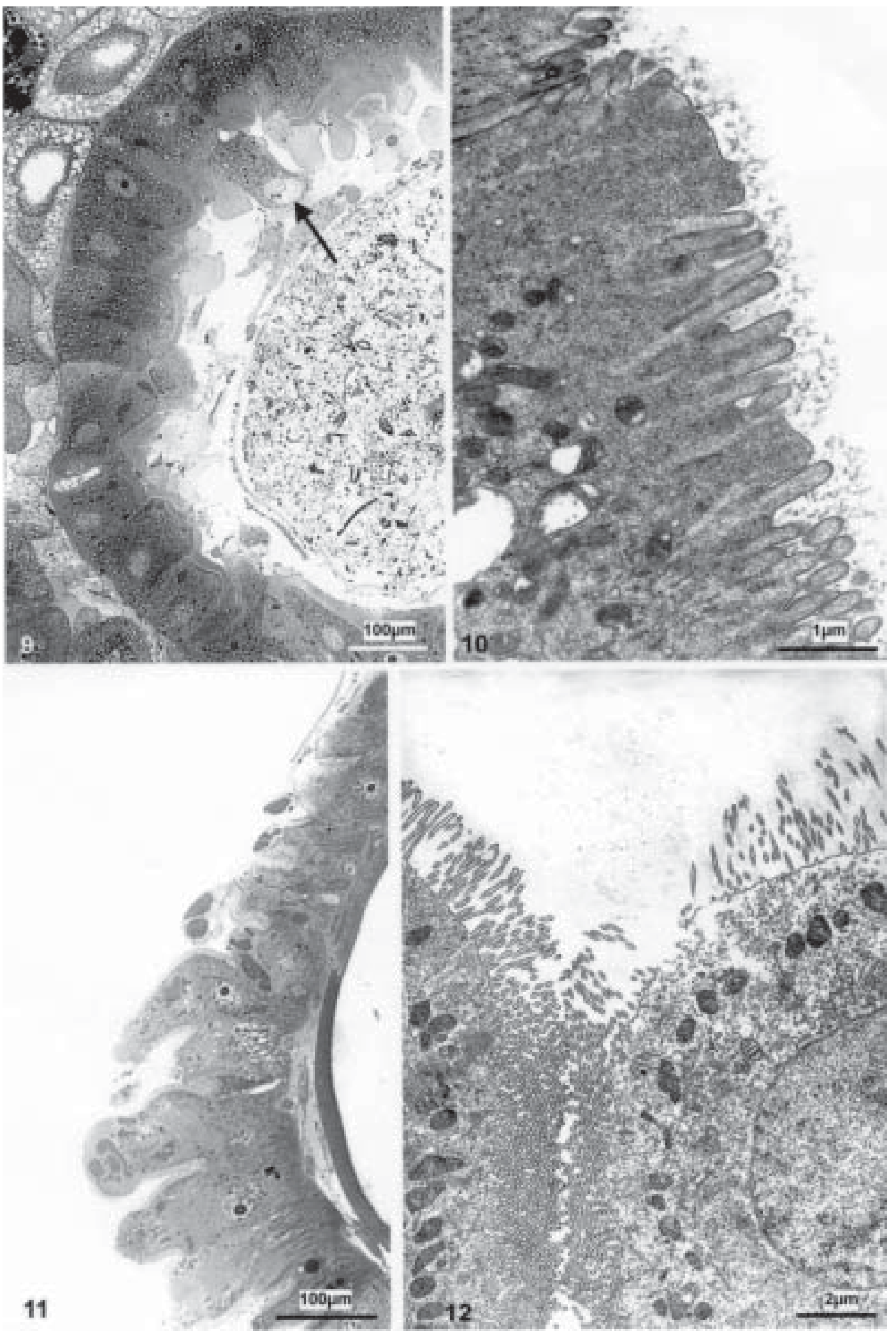

Fig. 9: columnar cells of the midgut of a larva after treatment of $1 \mathrm{~h}$ with $4 \mathrm{mg} / \mathrm{l}$ of Bacillus thuringiensis serovar israelensis (Bti) suspension. Note one elongated and detached columnar cell (arrow) and also disorganized nuclei and cytoplasmic structures; semithin section. Fig. 10: columnar cell of the midgut of a larva after treatment of $4 \mathrm{~h}$ with $4 \mathrm{mg} / \mathrm{l} \mathrm{of} \mathrm{Bti} \mathrm{suspension.} \mathrm{Note} \mathrm{swollen} \mathrm{mitochondria,}$ absence of plasmalema, disorganized and shortened and confluent microvilli membranes; transmission electron micrograph. Fig. 11: columnar cells of the midgut of a larva after treatment of $1 \mathrm{~h}$ with $6 \mathrm{mg} / \mathrm{l}$ of Bti suspension. Note that all cells are strongly modified, elongated and no continuously disposed brush border can be identified. Fig. 12: two adjacent columnar cells of the midgut of a larva after treatment of $1 \mathrm{~h}$ with $6 \mathrm{mg} / \mathrm{l}$ of Bti suspension. Note disorganized chromatin, alterated mitochondria and microvilli and cell individuation. 
experimental models (Percy \& Fast 1983, Charles \& Barjac 1983, Rey et al. 1998), as also in S. pertinax (Figs 5, 8). These vacuoles proceeded from enlarged rough endoplasmic cisterns that had lost their ribosomes (Percy \& Fast 1983).

This article is the first report of the histopathological effects of the Bti endotoxins in the midgut of $S$. pertinax larvae and the data obtained may contribute for better understanding the mode of action of this bacterial strain used as bioinsecticide against black fly larvae.

\section{ACKNOWLEDGEMENTS}

To Dr OM Barth, head of the Laboratory Electron Microscopy, Department of Virology, Instituto Oswaldo Cruz, for helpfull electron microscope utilities and critical review of the manuscript.

\section{REFERENCES}

Araújo-Coutinho CJPC 1995. Biological control program against simuliids in the state of São Paulo, Brazil. Mem Inst Oswaldo Cruz 90: 131-134.

Araújo-Coutinho CJPC, Viviani ABP, Freire NMS, Mello RP 2003. Evaluation of the impact of Bacillus thuringiensis serovar israelensis and Temephos, used for the control of Simulium (Chirostilbia) pertinax Kollar, 1832 (Diptera, Simuliidae) on the associated entomofauna, Paraty, Rio de Janeiro, Brazil. Mem Int Oswaldo Cruz 98: 697-702.

Aronson AI, Shai Y 2001. Why Bacillus thuringiensis insecticidal toxins are so effective: unique features of their mode of action. FEMS Microbiol Lett 195: 1-8.

Becker N 1990. Microbial control of mosquitoes and black flies. Proc Intl Coll Invert Pathol Microb Control, Adelaide, p. 84-89.

Cavados CFG 2000. Efeitos Histopatológicos das Deltaendotoxinas de Bacillus thuringiensis Sorovar israelensis em Larvas de Simulium pertinax (Diptera: Simuliidae), $\mathrm{PhD}$ Thesis, UFRRJ, Seropédica, 110 pp.

Cavados CFG, Chaves JQ, Queiroz MMC, Freire NMS, Rabinovitch L 1998. An assessment of the biological activity of Bacillus thuringiensis LFB-FIOCRUZ 907 in Chrysomya megacephala (Diptera, Calliphoridae). Israel J Entomol XXXII: 117-123.

Cavados CFG, Fonseca RN, Chaves Q, Rabinovitch L, AraújoCoutinho CJPC 2001. Identification of entomopathogenic Bacillus isolated from Simulium (Diptera, Simuliidae) larvae. Mem Inst Oswaldo Cruz 96: 1017-1021.

Charles J-F, de Barjac H 1983. Action des cristaux de Bacillus thuringiensis var.israelensis sur l'intestin moyen des larves de Aedes aegypti, en microscopie életronique. Ann Microbiol (Inst Pasteur) 134 A: 197-218.

De Barjac H 1978. Um nouveau candidat a la lutte biologique contre les moustiques: Bacillus thuringiensis var. israelensis. Entomophaga 23: 309-319.

Gerais BB, Ribeiro TC 1986. Relatos de casos - Oncocercose: primeiro caso autóctone da região Centro-oeste do Brasil. Rev Soc Bras Med Trop 19: 105-107.

Gill SS 1992. The mode of action of Bacillus thuringiensis endotoxins. Ann Rev Entomol 37: 615-636.

Goldberg LH, Margalit J 1977. A bacterial spore demonstrating rapid larvicidal activity against Anopheles sergentii, Uranotaenia unguiculata, Culex univitatus Aedes aegypti and Culex pipiens. Mosq News 37: 355-358.
Humprey CD, Pittman EE 1974. A simple methylene blueazure II basic fuchsin stain for epoxi-embedded tissue sections. Stain Tecnol 49: 9.

Knowles BH 1994. Mechanism of action of Bacillus thuringiensis insecticidal $\delta$-endotoxin. Adv Insect Physiol 24: 275-308.

Lacey LA, Federici BA 1979. Pathogenesis and midgut histopathology of Bacillus thuringiensis in Simulium vittatum (Diptera: Simuliidae). J Invertebr Pathol 33: 171-182.

Lacey LA, Escaffre H, Philippson B, Seketeli A, Guillet P 1982. Large river treatment with Bacillus thuringiensis (H-14) for the control of Simulium dammnosum S.I in the onchocerciasis control programme. Z Tropenmed Parasitol 33: 97101.

Lahkim-Tsor L, Pascar-Gluzman C, Margalit J, Barak Z 1983. Larvicidal activity of Bacillus thuringiensis subsp. israelensis, serovar H-14 in Aedes aegypti: histophatological studies. J Invertebr Pathol 41: 104-116.

Maia-Herzog M, Shelley AJ, Bradley JE, Luna Dias APA, Calvão RHS, Lowry CA, Camargo M, Rubio JM, Post RJ, Coelho GE 1999. Discovery of a new focus of human onchocerciasis in central Brazil. Trans $R$ Soc Trop Med Hyg 93: 1-5.

Mardini LB, Souza MAT, Rabinovitch L, Alves RSA, Silva CMB 1999. Field studies with the bacterial larvicide INPALBAC for Simulium spp. control in Rio Grande do Sul, Brazil. Mem Inst Oswaldo Cruz 94: 679-681.

Percy J, Fast PG 1983. Bacillus thuringiensis crystal toxin: ultrastructural studies of its effect on silkworm midgut cells. J Invertebr Pathol 41: 86-98.

Rabinovitch L, Cavados CFG, Chaves JQ, Coutinho CJPCA, Silva, KRA, Seldin L 1999. A new strain of Bacillus thuringiensis serovar israelensis very active against black fly larvae. Mem Inst Oswaldo Cruz 94: 683-685.

Rabinovitch L, Palmeira ML, Silva SM 1975. Spontaneous Spo mutant of Bacillus licheniformis with increased respiratory metabolism. Rev Microbiol (São Paulo) 6: 47-49.

Rabinovitch L, Silva CMB, Alves RSA, Consoli RAGB, Santos BS, Lamounier MA 1998. Produção de bioinseticidas à base de Bacillus thuringiensis e Bacillus sphaericus. In Anais do $4^{\circ}$. Simpósio de Controle Biológico - IV Siconbiol, Rio de Janeiro, RJ, p. 479-483.

Regis L, Silva-Filha MH, Nielsen-LeRoux C, Charles J-F 2001. Bacteriological larvicides of dipteran disease vectors. Trends in Parasitol 17: 377-379.

Rey D, Long A, Pautou, MP, Meyran JC 1998. Comparative histopathology of some Diptera and Crustacea of aquatic alpine ecosystems, after treatment with Bacillus thuringiensis var. israelensis. Entomol Exper Applicata 88: 255-263.

Reynolds ES 1963. The use of lead citrate at high $\mathrm{pH}$ as an electron-opaque stain in electron microscopy. J Cell Biol 17: 208-212.

Richardson KC, Jarret CJ, Finke EH 1960. Embedding in epoxy resins for ultrathin sectioning in electron microscopy. Stain Technol 35: 313-323.

Ruiz LM, Segura C, Trujillo J, Orduz S 2004. In vivo binding of the Cry $11 \mathrm{Bb}$ toxin of Bacillus thuringiensis subsp. medellin to the midgut of mosquito larvae. Mem Inst Oswaldo Cruz. 99: 73-79.

Schnepf E, Crickmore N, van Rie J, Lereclus D, Baum J, Feitelson J, Zeigler DR, Dean DH 1998. Bacillus thuringiensis and its pesticidal crystal proteins. Microbiol and Mol Biol Rev 62: 775-806. 